\title{
CORRIGENDUM
}

\section{Risk of fever and sepsis evaluations following routine immunizations in the neonatal intensive care unit}

\author{
AM Navar-Boggan, NA Halsey, WC Golden, GJ Escobar, M Massolo and NP Klein
}

Journal of Perinatology (2010) 30, 632; doi:10.1038/jp.2010.60

Correction to: Journal of Perinatology (2010) 30, 604-609; doi:10.1038/jp.2010.8; published online 25 February 2010

Following the online publication of this article, an error was identified in the contact information for the corresponding author; 'Duke University School of Medicine' was erroneously included. The correct contact information is listed below:

Dr NP Klein, Kaiser Permanente Vaccine Study Center, 1 Kaiser Plaza, 16th Floor, Oakland, CA 94612, USA.

E-mail: Nicola.Klein@kp.org 